\title{
PENGARUH SIKAP SKEPTIS, INDEPENDENSI AUDITOR, PENERAPAN KODE ETIK AKUNTAN PUBLIK, DAN AKUNTABILITAS TERHADAP KUALITAS AUDIT \\ (STUDI EMPIRIS PADA KAP DI WILAYAH JAKARTA SELATAN)
}

\author{
Nia Tresnawaty, SE.,M.Ak \\ dan \\ Melisa Bhetty Br Ginting
}

Fakultas Ekonomi Universitas Satya Negara Indonesia, Jakarta Jl. Arteri Pondok Indah No. 11, Jakarta Selatan, DKI Jakarta 12240

\begin{abstract}
ABSTRAK
Auditor akan mampu menghasilkan laporan yang memiliki kualitas baik dengan menanamkan sikap skeptis dan independen dalam memeriksa laporan keuangan. Hal ini berdasarkan pada penerapan kode etik akuntan publik sebagai prinsip dasar yang mengatur etika profesi akuntan publik, selain itu dengan adanya akuntabilitas maka seorang auditor akan mampu meningkatkan kualitas hasil pekerjaannya. Tujuan penelitian ini adalah untuk mengetahui Pengaruh Sikap Skeptis, Independensi Auditor, Penerapan Kode Etik Akuntan Publik dan Akuntabilitas terhadap Kualitas Audit pada KAP di Jakarta Selatan secara parsial dan simultan. Metode penelitian yang dilakukan adalah penelitian kausal. Populasi dalam penelitian ini adalah auditor pada Kantor Akuntan Publik Jakarta Selatan dengan responden sebanyak 60 orang. Data yang digunakan adalah data primer. Metode pengumpulan data menggunakan teknik kuesioner. Analisis data yang digunakan adalah kuantitatif dengan menggunakan SPSS versi 22.0.

Hasil penelitian ini secara parsial menunjukkan bahwa empat variabel yaitu, Sikap Skeptis, Independensi Auditor, Penerapan Kode Etik Akuntan Publik dan Akuntabilitas berpengaruh signifikan dan positif terhadap kualitas audit. Sedangkan secara simultan Sikap Skeptis, Independensi Auditor, Penerapan Kode Etik Akuntan Publik dan Akuntabilitas berpengaruh signifikan dan positif terhadap kualitas audit
\end{abstract}

Kata kunci: Sikap Skeptis, Independensi Auditor, Penerapan Kode Etik Akuntan Publik, Akuntabilitas dan Kualitas Audit. 


\begin{abstract}
Auditors will be able to generate reports that have good quality by instilling skepticism and independent examination of the financial statements. It is based on the application of the code of ethics of public accountants as the basic principles that govern the professional ethics of public accountants, in addition to the lack of accountability then the auditor will be able to improve the quality of his work. The purpose of this study was to determine the effect of Skeptical Attitude, Auditor Independence, Implementation of the Code of Conduct and Accountability to Public Accountant Audit Quality in KAP in South Jakarta partially and simultaneously. The research method is causal research. The population in this study was an auditor at the Public Accounting Office in South Jakarta by respondents as many as 60 people. The data used are primary data. Methods of data collection using questionnaire techniques. Analysis of the data used is quantitatively using SPSS version 22.0.

Partial results of this study showed that four variables, Attitude Skeptical, Auditor Independence, Implementation of the Code of Ethics of Certified Public Accountants and Accountability significant and positive impact on audit quality. While simultaneously Attitude Skeptical, Auditor Independence, Implementation of the Code of Ethics of Certified Public Accountants and Accountability significant and positive impact on audit quality
\end{abstract}

Keywords: Attitude Skeptical, Auditor Independence, Implementation of the Code of Public Accountants, Accountability and Quality Audit. 


\section{PENDAHULUAN}

Bentuk pertanggung jawaban manajemen dalam mengambil keputusan adalah dengan menyajikan informasi keuangan dalam bentuk laporan keuangan. Apabila manajemen salah dalam menyajikan informasi keuangan tersebut, maka akibatnya mereka akan mengalami kerugian. Oleh karena itu FASB memberikan dua karakteristik penting yang harus dimiliki oleh laporan keuangan agar bermanfaat dan berguna bagi pemakai informasi tersebut. Reliabel (dapat diandalkan) dan relevance (relevan) adalah dua hal penting yang seharusnya mampu dimiliki oleh laporan keuangan yang dihasilkan oleh suatu entitas (Singgih dan Bawono, 2010). Namun, untuk mengukur tingkat karakteristik reliabel (dapat diandalkan) dan relevance (relevan) untuk suatu laporan keuangan sulit dilakukan. Hal ini dikarenakan adanya benturan kepentingan yang terjadi diantara manajemen (agent) dengan pemilik (principal). Untuk menengahi perbedaan kepentingan ini maka diperlukan adanya pihak ketiga yaitu auditor yang menyelaraskan asimetri informasi ini guna mewujudkan laporan keuangan yang sesuai dengan dua karakteristik yang disyaratkan oleh FASB.

Pada era globalisasi sekarang ini, dengan berkembangnya Profesi Akuntan Publik sejalan dengan bertambahnya Kantor Akuntan Publik (KAP) yang tersebar. Namun hal tersebut tidak langsung mampu meningkatkan kepercayaan masyarakat akan laporan audit yang dihasilkan. Sejumlah kasus kegagalan keuangan lainnya membuat auditor harus memperhatikan kualitas audit dihasilkannya.

AAERs (Accounting and Auditing Releases) menyatakan bahwa salah satu penyebab kegagalan SEC selama 11 periode (Januari 1987-Desember 1997) dalam mendeteksi kecurangan adalah rendahnya tingkat skeptisme professional audit yang dimiliki, hal ini diungkap dalam Rina Rusyanti (2010). Rendahnya sikap skeptisme professional yang dimiliki akan mengurangi kemampuan auditor dalam mendeteksi kecurangan sehingga auditor tidak mampu memenuhi tuntutan untuk menghasilkan laporan yang berkualitas. Padahal jika auditor mampu mendeteksi adanya temuan dan keadaan yang sesungguhnya dalam laporan keuangan klien maka kualitas audit yang dihasilkan akan semakin baik.

Sikap Skeptis yang harus dimiliki auditor tidak hanya dapat digunakan dalam pelaksanaan audit dan penyusunan laporan, namun dalam melakukan pekerjaan lapangan serta untuk mendapatkan bukti audit kompeten yang cukup maka seorang auditor pun wajib untuk menjunjung skeptisme guna meningkatkan kualitas dari laporan yang dihasilkan.

Standar umum kedua dalam (SPAP 2011 Seksi 220.1 PSA No.4) menyatakan bahwa kepercayaan masyarakat akan menurun apabila sikap mental seorang auditor berkurang disebabkan oleh hal-hal yang dapat mengganggu independensi seorang auditor.

Rendahnya sikap independensi yang dimiliki auditor akan mempengaruhi auditor dalam penerapan Kode Etik Profesi Akuntan Publik sehingga dapat menurunkan kualitas audit yang dihasilkan. Menurut penelitian yang dilakukan oleh Setiawan (2011) kualitas audit perlu ditingkatkan untuk meningkatkan kepercayaan masyarakat. Ketidaktaatan auditor pada prosedur dalam Standar Profesi Akuntan Publik (SPAP) tidak hanya merugikan Kantor Akuntan Publik secara ekonomis, juga dapat mengurangi reputasi akuntan publik dimata masyarakat, dan menghilangkan kepercayaan kreditor dan investor dipasar modal. Dalam menjalankan jasa profesionalnya auditor seharusnya berpedoman pada Kode Etik Profesi Akuntan Publik sebagai aturan dasar dalam melaksanakan audit. 
Mardisar dan Sari (2007) dalam Singgih (2010) mengungkapkan bahwa rasa tanggung jawab (akuntabilitas) yang dimiliki oleh auditor dalam menyelesaikan pekerjaan audit mampu mempengaruhi kualitas hasil pekerjaan auditor sehingga akuntabilitas menjadi salah satu faktor penting yang harus dimiliki auditor. Penelitian yang dilakukan oleh Arianti, dkk. (2014) menyatakan bahwa dengan adanya profesionalisme dari seorang auditor, maka akan menghasilkan pekerjaan yang berkualitas, karena dengan profesionalisme berarti auditor telah menggunakan kemampuan dalam melaksanakan audit secara maksimal serta melaksanakan pekerjaan dengan etika yang tinggi. Jika sebagai seorang auditor menyadari akan tanggung jawabnya maka ia akan melaksanakan pekerjaannya dengan sebaik-baiknya. Mengabdikan diri pada sebuah profesi adalah komitmen yang terbentuk secara sukarela dalam diri seseorang,

Pengaruh Sikap Skeptis, Independensi, Penerapan Kode Etik, dan Akuntabilitas terhadap Kualitas Audit, hasil dari penelitian mendapatkan bahwa Sikap Skeptis tidak memiliki pengaruh terhadap Kualitas Audit. Independensi Auditor juga tidak memiliki pengaruh terhadap Kualitas Audit. Penerapan Kode Etik Akuntan Publik berpengaruh Positif terhadap Kualitas Audit, sedangkan Akuntabilitas tidak memiliki pengaruh terhadap Kualitas Audit. Untuk menghasilkan Kualitas Audit yang baik, maka penting bagi Akuntan publik untuk menerapkan Kode Etik akuntan publik agar mampu meningkatkan kepercayaan para pengguna laporan keuangan. Ade Wisteri sawitri nandari (2015).

Berdasarkan pemaparan diatas, maka yang menjadi permasalahan dalam penelitian ini yaitu Bagaimana pengaruh Sikap Skeptis, Independensi Auditor, Penerapan Kode Etik Akuntan Publik, dan Akuntabilitas terhadap Kualitas Audit. Mengingat arti penting dari penelitian ini, maka tujuan dari penelitian ini adalah untuk mengetahui PENGARUH SIKAP SKEPTIS, INDEPENDENSI AUDITOR, PENERAPAN KODE ETIK AKUNTAN PUBLIK, DAN AKUNTABILITAS TERHADAP KUALITAS AUDIT.

\section{LANDASAN TEORI}

\section{Teori Keagenan}

Teori keagenan dikembangkan oleh Jensen dan Meckling pada tahun 1976 menjelaskan perbedaan kepentingan antara manajer dengan pemilik. Agency teory (teori keagenan) membahas mengenai perbedaan kepentingan yang dapat muncul antara principal dan agent (Putra Astika, 2010:64). Manajemen dapat dikatakan sebagai agent sedangkan pemegang saham bertindak sebagai principal. Seorang agent adalah orang yang sengaja dipekerjakan oleh principal dalam menjalankan usahanya. Sedangkan principal adalah orang yang mempekerjakan agent. Agent bertanggungjawab untuk memberikan informasi dalam bentuk laporan keuangan kepada principal. Namun disini terjadi perbedaan kepentingan antara agen dengan prinsipal yang masing-masing memiliki tujuan yang berbeda. Agen menginginkan agar laporan yang dihasilkan dapat memperoleh laba setinggi-tingginya. dilakukan untuk meningkatkan bonus manajeman. Di pihak yang berbeda, prinsipal justru mengutamakan laporan keuangan yang lebih berorientasi pada keberlangsungan perusahaan. 
Perbedaan ini didukung dengan asimetri informasi yang terjadi diantara kedua belah pihak. Manajemen selaku agen yang secara langsung terjun untuk melakukan pekerjaan lapangan lebih banyak mengetahui tentang informasi mengenai perusahaan jika dibandingkan dengan principal. Disinilah diperlukan auditor yang independen sebagai pihak ketiga yang menengahi konflik yang terjadi antara manajemen dengan pemegang saham. Auditor independen mempunyai tanggung jawab utama dalam melaksanakan fungsi pengauditannya terhadap laporan keuangan yang diterbitkan oleh klien agar memiliki karakteristik reliabel dan relevance.

\section{Sikap Skeptis dan Kualitas Audit}

Sikap Skeptis memiliki pengaruh dalam mengevaluasi bukti audit yang diberikan manajemen untuk mendukung terjaminnya kualitas audit yang dihasilkan. Menurut PSA No. 04 (SA Seksi 230) dalam SPAP (2011:230.2) menyatakan bahwa skeptisme profesional harus digunakan dalam proses pengumpulan dan penilaian bukti selama proses audit. Rina Rusyanti (2010) menunjukkan bahwa sikap skeptis berpengaruh terhadap kualitas audit. Penelitian lainnya juga mengungkapkan variabel skeptisme berpengaruh positif terhadap kualitas audit, Indira Januarti (2010). Ini menunjukkan bahwa semakin tinggi skeptisme profesional yang dimiliki maka akan semakin baik kualitas audit dari laporan keuangan. Berdasarkan hal tersebut hipotesis dalam penelitian ini yaitu: H1:Sikap Skeptis berpengaruh positif terhadap Kualitas Audit.

\section{Independensi dan Kualitas Audit}

Independensi merupakan standar umum nomor dua, yaitu standar pekerjaan lapangan yang ditetapkan oleh Institut Akuntan Publik Indonesia. Standar Profesional Akuntan Publik mengharuskan bahwa auditor dalam penugasannya harus mempertahankan sikap mental independen. Arens (2006) mendefinisikan independensi dalam pengauditan sebagai penggunaan cara pandang yang tidak bias dalam pelaksanaan pengujian audit, evaluasi hasil pengujian tersebut, dan pelaporan hasil temuan audit. Penelitian yang dilakukan oleh Singgih dan Bawono (2010) mendukung hipotesis bahwa independensi memiliki pengaruh yang signifikan terhadap kualitas audit. Begitupula penelitian dari Mabruri dan Winarna (2010) juga mendukung hipotesis bahwa independensi secara parsial berpengaruh positif signifikan terhadap kualitas audit. Berdasarkan hal tersebut maka hipotesis kedua dalam penelitian ini yaitu: $\mathrm{H} 2$ : Independensi berpengaruh positif terhadap Kualitas Audit.

\section{Penerapan Kode Etik Akuntan Publik dan Kualitas Audit}

Kode etik memiliki pengaruh terhadap kualitas audit dalam penerapannya agar akuntan publik dapat melaksanakan pekerjaannya yang sesuai dengan aturan yang relevan. Menurut Halim (2008:29) salah satu faktor yang berpengaruh terhadap kualitas audit adalah ketaatan auditor terhadap kode etik, yang terefleksikan oleh sikap independensi, obyektivitas, integritas dan lain sebagainya. Dengan tingkat independensi yang tinggi akan menghasilkan audit yang berkualitas tinggi. Berdasarkan hal tersebut maka hipotesis dalam penelitian ini yaitu: H3:Penerapan Kode Etik Akuntan Publik berpengaruh positif terhadap Kualitas Audit. 


\section{Akuntabilitas dan Kualitas Audit}

Akuntabilitas penting sebagai bentuk kewajiban sosial yang dapat dilakukan oleh akuntan publik dalam menjaga kualitas auditnya. Beberapa penelitian sebelumnya menemukan bahwa akuntabilitas dan kualitas audit memiliki hubungan sejajar. Tetclock (1984) dalam Diani Mardisar dan Ria Nelly Sari (2007) mendefinisikan akuntabilitas sebagai dorongan psikologi yang membuat seseorang berusaha mempertanggungjawabkan semua tindakan dan keputusan yang diambil kepada lingkungannya.

Penelitian mengenai akuntabilitas pernah dilakukan sebelumnya oleh Mardisar dan Sary (2007) yang menunujukan hasil bahwa akuntabilitas berpengaruh positif terhadap kualitas audit di Kantor Akuntan Publik. maka berdasarkan hal tersebut maka hipotesis dalam penelitian ini yaitu: H4:Akuntabilitas berpengaruh positif terhadap Kualitas Audit

\section{METODE PENELITIAN}

\section{Populasi dan Sampel}

Penelitian ini dilakukan pada Kantor Akuntan Publik yang berlokasi di Jakarta Selatan. dengan menggunakan data primer yang dikumpulkan melalui kuesioner. Populasi yang digunakan sebanyak 68 auditor. Metode penentuan sampel dalam penelitian ini adalah metode purposive sampling dengan kriteria bekerja di Kantor Akuntan Publik di wilayah Jakarta Selatan dalam kurun waktu 2 tahun dan pernah ditugaskan dalam pekerjaan lapangan. Berdasarkan kriteria, maka sampel yang terpilih sebanyak 60 auditor.

\section{Sumber Data}

\section{Data Primer}

Data Primer adalah data yang diperoleh secara langsung dari subjek penelitian dengan menggunakan pengukuran atau pengambilan data langsung pada subjek sebagai sumber informasi yang dicari. Untuk memperoleh data tersebut, penelitian ini menggunakan metode survei dengan teknik kuesioner dengan cara mengedarkan daftar pertanyaan yang akan diisi oleh responden.

\section{Teknik Pengumpulan Data} diantaranya:

Terdapat beberapa metode dalam mengumpulkan data-data yang diperoleh,

1) Kuesioner

Kuesioner yang disebarkan berupa daftar pertanyaan dan pernyataan tertulis kepada responden mengenai Pengaruh Sikap Skeptis, Independensi Auditor, Penerapan Kode Etik Akuntan Publik, dan Akuntabilitas terhadap Kualitas Audit di Kantor Akuntan Publik di wilayah Jakarta Selatan .

2) Dokumentasi

Dokumentasi dilakukan dengan melihat catatan atau dokumen seperti membaca bukubuku literatur yang terkait dengan penelitian (Sugiyono, 2009:199). 


\section{Variabel Penelitian}

Penelitian ini menggunakan variabel Sikap Skeptis, Independensi Auditor, Penerapan Kode Etik Akuntan Publik, dan Akuntabilitas.Variabel dependen yang digunakan adalah Kualitas Audit. Penilaian seluruh variabel yang digunakan dengan skala Likert.

\section{Teknik Analisis Data}

\section{Analisis Deskriptif}

Statistik deskriptif menggambarkan atau mendepenelitiankan suatu data yang dilihat dari nilai rata-rata (mean), standar deviasi, varian, maksimum, minimum berdasarkan data yang diperoleh dari jawaban kuisioner dengan menggunakan tabulasi data.

\section{Pengujian Analisis Regresi Linier Berganda}

Analisis linear berganda digunakan untuk memecahkan rumusan masalah yang ada, yaitu untuk melihat pengaruh diantara dua variabel atau lebih. Persamaan model regresi linear berganda ditunjukkan oleh persamaan regresi berikut:

$\mathrm{Y}=\alpha+\beta 1 \mathrm{X} 1+\beta 2 \mathrm{X} 2+\beta 3 \mathrm{X} 3+\beta 4 \mathrm{X} 4+\mathrm{e}$

Keterangan:

$\mathrm{Y} \quad=$ kualitas audit

$\alpha \quad=$ Nilai konstanta $($ nilai $\mathrm{Y}$ jika $\mathrm{X}=0$ )

$\beta \quad=$ Koefisisen Variabel $\mathrm{X}$

$\mathrm{X} 1=$ Sikap skeptis

$\mathrm{X} 2=$ Independensi auditor

$\mathrm{X} 3=$ Penerapan kode etik akuntan publik

$\mathrm{X} 4=$ Akuntabilitas

$\mathrm{e} \quad=$ Error

Dalam analisis regresi berganda menggunakan koefisien determinasi (Adjusted $R$ square) dalam menerangkan variasi variabel dependen (Y). Teknik analisis ini juga memerlukan Uji F yang dilakukan dengan melihat nilai signifikansi pada tabel Annova. Uji t digunakan untuk membuktikan hipotesis dalam penelitian ini. Bila nilai signifikansi annova $<\alpha$ $=0,05$ maka model ini dikatakan layak atau variabel bebas mampu menjelaskan variabel terikat. 


\section{HASIL DAN PEMBAHASAN}

Berdasarkan hasil perhitungan regresi yang telah dilakukan, maka didapat nilai untuk koefisien regresi dari tiap variabel sebagai berikut

\section{Tabel}

Hasil Analisis Regresi

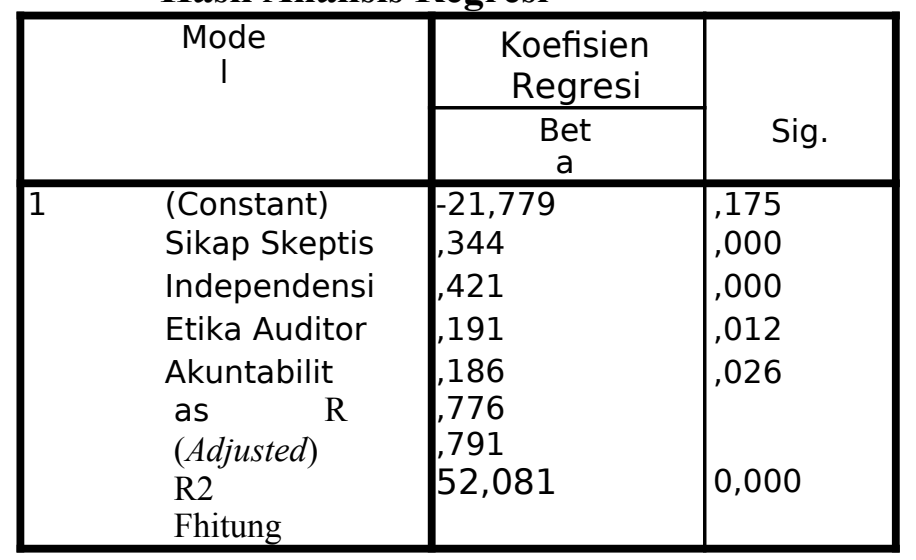

Sumber Data : Output SPSS 22

Dari tabel 4.25 di atas dapat diketahui model persamaan regresi linier berganda sebagai berikut :

$$
\begin{aligned}
& \mathbf{Y}=\boldsymbol{\alpha}+\boldsymbol{\beta}_{1} \mathbf{X}_{1}+\boldsymbol{\beta}_{\mathbf{2}} \mathbf{X}_{\mathbf{2}}+\boldsymbol{\beta}_{\mathbf{3}} \mathbf{X}_{\mathbf{3}}+\boldsymbol{\beta}_{4} \mathbf{X}_{4}+\boldsymbol{\beta}_{5} \mathbf{X}_{\mathbf{5}}+\text { e atau } \\
& Y=-21,779+0,344+0,421+0,191+0,186
\end{aligned}
$$

\section{Pengaruh Sikap Skeptis terhadap Kualitas Audit}

Hipotesis pertama menyatakan bahwa sikap skeptis tidak memiliki pengaruh secara signifikan terhadap Kualitas Audit. Setelah dilakukan pengujian, maka didapatkan bahwa variable Sikap Skeptis memiliki pengaruh positif terhadap kualitas audit di Kantor Akuntan Publik di wilayah Jakarta selatan. Kondisi ini menggambarkan bahwa semakin tinggi tingkat skeptisme profesional yang dimiliki auditor, maka kualitas audit yang dihasilkan akan semakin baik. Skeptisme profesional ditekankan dalam profesi yang berhubungan dengan pengumpulan dan penilaian bukti secara kritis. Auditor perlu menerapkan sikap skeptis dalam mengevaluasi bukti audit, sehingga dapat memperkirakan kemungkinan yang dapat terjadi, seperti bukti yang menyesatkan, dan tidak lengkap. Bagi akuntan publik, kepercayaan yang berasal dari klien atas kualitas audit sangatlah diutamakan. Hasil yang diperoleh ini berbeda dengan penelitian yang dilakukan oleh Ade Wisteri sawitri nandari (2015) yang menyatakan Sikap Skeptis atau sikap tidak mudah percaya tidak memiliki pengaruh terhadap Kualitas Audit. 


\section{Pengaruh Independensi terhadap Kualitas Audit}

Hipotesis kedua menyatakan bahwa independensi auditor berpengaruh positif terhadap kualitas audit di Kantor Akuntan Publik. Setelah dilakukan pengujian, maka didapatkan bahwa Independensi berpengaruh positif terhadap kualitas audit di wilayah Jakarta selatan. Independensi seseorang dapat dibangun melalui pengalaman yang telah mereka peroleh. Independensi tidak dapat diturunkan dari sikap mental auditor tetapi harus dibangun berdasarkan kesadaran dari masing-masing auditor. Hasil penelitian ini sejalan dengan pendapat Restu Agusti dan Nastia Putri Pertiwi (2013) yang menyimpulkan bahwa independensi berpengaruh positif terhadap Kualitas Audit.

\section{Pengaruh Penerapan Kode Etik Akuntan Publik terhadap Kualitas Audit}

Hipotesis ketiga menyatakan bahwa Kode Etik Akuntan Publik berpengaruh positif terhadap Kualitas Audit di Kantor Akuntan Publik. Setelah dilakukan pengujian, maka didapatkan bahwa Kode Etik Akuntan Publik berpengaruh terhadap Kualitas Audit di wilayah Jakarta Selatan. Ade Wisteri sawitri nandari (2015) pun menyatakan bahwa etika profesi yang dimiliki auditor memiliki pengaruh terhadap kualitas audit yang akan dihasilkan oleh auditor tersebut.

\section{Pengaruh Akuntabilitas terhadap Kualitas Audit}

Hipotesis keempat menyatakan bahwa Akuntabilitas berpengaruh positif terhadap kualitas audit di Kantor Akuntan Publik. Setelah dilakukan pengujian, maka didapatkan bahwa Akuntabilitas memiliki pengaruh secara signifikan dan Positif terhadap Kualitas Audit di Kantor Akuntan Publik di wilayah Jakarta selatan. Mardisar dan Sari (2007) dalam Singgih (2010) mengungkapkan bahwa rasa tanggung jawab (akuntabilitas) yang dimiliki oleh auditor dalam menyelesaikan pekerjaan audit mampu mempengaruhi kualitas hasil pekerjaan auditor sehingga akuntabilitas menjadi salah satu faktor penting yang harus dimiliki auditor. Jika sebagai seorang auditor menyadari akan tanggung jawabnya maka ia akan melaksanakan pekerjaannya dengan sebaik-baiknya. Mengabdikan diri pada sebuah profesi adalah komitmen yang terbentuk secara sukarela dalam diri seseorang.

\section{KESIMPULAN}

Berdasarkan hasil penelitian mengenai pengaruh Sikap Skeptis, Independensi Auditor, Penerapan Kode Etik dan Akuntabilitas terhadap kinerja audit yang dilakukan pada Kantor Akuntan Publik di wilayah Jakarta Selatan, maka dapat ditarik kesimpulan sebagai berikut:

1. Sikap Skeptis berpengaruh secara signifikan dan positif terhadap kualitas audit, Kondisi ini menggambarkan bahwa semakin tinggi tingkat kompetensi auditor, maka akan semakin tinggi pula tingkat skeptis yang dimiliki.

2. Independensi Auditor berpengaruh secara signifikan dan positif terhadap kualitas audit, Artinya Independensi seseorang dapat dibangun melalui pengalaman yang telah mereka peroleh. independensi tidak dapat diturunkan dari sikap mental auditor tetapi harus dibangun berdasarkan kesadaran dari masing-masing auditor. 
3. Penerapan Kode Etik berpengaruh secara signifikan dan positif terhadap kualitas audit, Artinya semakin tinggi kode etik akuntan publik yang ditaati dan diterapkan maka kualitas audit yang dihasilkan akan semakin tinggi.

4. Akuntabilitas berpengaruh secara signifikan dan positif terhadap kualitas audit, Artinya rasa tanggung jawab yang dimiliki oleh auditor dalam menyelesaikan pekerjaan audit mampu mempengaruhi kualitas hasil pekerjaan auditor sehingga akuntabilitas menjadi salah satu faktor penting yang harus dimiliki auditor.

\section{SARAN}

Beberapa saran yang dapat diberikan oleh peneliti sebagai berikut :

a) Peneliti menyarankan agar peneliti selanjutnya melakukan penelitian dalam lingkup yang lebih luas dengan waktu yang cukup sehingga dapat diperoleh data yang cukup dan hasil analisa akan jauh lebih akurat.

b) Peneliti menyarankan agar peneliti selanjutnya menggunakan responden dengan jumlah yang lebih besar dari sampel penelitian ini sehingga proses pengolahan data, analisis dan interprestasi hasil jauh akan lebih baik dari penelitian ini.

c) Peneliti menyarankan agar peneliti selanjutnya dapat mengembangkan penelitian dengan menambahkan faktor-faktor dan variable lain diluar model penelitian ini untuk menambahkan daftar literature penelitian yang mungkin mempunyai pengaruh terhadap kualitas audit.

d) Peneliti menyarankan Kantor Akuntan Publik sebaiknya sering memberikan seminar atau pelatihan khusus bagi para Auditornya agar Auditor semakin berkompeten karna kompetensi merupakan hal yang sangat penting dalam proses Audit.

\section{DAFTAR PUSTAKA}

Abdul Halim. 2008. Auditing 1 Dasar-dasar Audit Laporan Keuangan. Yogyakarta : UPP AMP YKPN.

Ade Wisteri sawitri nandari1, 2015. Pengaruh Sikap Skeptis, Independensi, Penerapan Kode Etik, dan Akuntabilitas terhadap Kualitas Audit. Universitas Udayana.

Arianti, Komang Pariardi,Edi Sujana, dan I Made Pradana Adi Putra. 2014. Pengaruh Integritas, Obyektifitas, dan Akuntabilitas Terhadap Kuliatas Audit di Pemerintahan Daerah (Studi Pada Inspektorat Kabupaten Buleleng). E-Journal S1 Akuntansi Universitas Pendidikan Ganesha Jurusan Akuntansi S1 (Vol: 2 No: 1 Tahun 2014).

Institut Akuntan Publik Indonesia-Kompartemen Akuntan Publik (IAPI-KAP). (2011). SPAP. Jakarta: Salemba Empat.

Indira Januarti dan Faisal. 2010. Pengaruh Moral Reasoning dan Skeptisme Profesional Auditor Pemerintah Terhadap Kualitas Audit Laporan Keuangan Pemerintah Daerah. Dalam Simposium Nasional Akuntansi XIII Purwokerto 2010.

Mabruri, Havidz dan Jaka Winarna. 2010. Analisis Faktor-faktor yang Mempengaruhi Kualitas Hasil Audit di Lingkungan Pemerintah Daerah. Dalam Simposium Nasional Akuntansi XIII Purwokerto 2010.

Mardisar, Diani dan Sari, Ria Nelly. (2007). Pengaruh Akuntabilitas dan Pengetahuan terhadap Kualitas Hasil Kerja Auditor. Simposium Nasional Akuntansi X. Makasar.

Putra Astika, I.B. 2010. Buku Ajar Teori Akuntansi: Konsep-Konsep Dasar Akuntansi Keuangan. Fakultas Ekonomi Universitas Udayana:Denpasar. 
Rina Rusyanti. 2010. Pengaruh Sikap Skeptisme Auditor, Profesionalisme Auditor Dan Tekanan Anggaran Waktu Terhadap Kualitas Audit. Penelitian:Universitas Islam Negeri Syarif Hidayatullah.

Setiawan, Anggi Okta. 2011. Pengaruh Kompetensi dan Independensi Auditor Terhadap Kualitas Audit. Penelitian:Sekolah Tinggi Ilmu Ekonomi Perbanas Surabaya

Singgih, Elisha Muliani dan Icuk Rangga Bawono, 2009. Faktor-Faktor Dalam Diri Auditor dan Kualitas Audit: Studi pada KAP , Big Four" di Indonesia.Dalam Simposium Nasional Akuntansi XIII Purwokerto.

Sugiyono. 2009. Metode Penelitian Bisnis. Bandung:Alfabeta. 